\title{
Selection of Remote Sensing Images And Evapotranspiration Models On Complex Land Surfaces for a Humid Karst Catchment
}

Rongfei Zhang ( $\nabla$ rongfei330@cqu.edu.cn )

Chongqing University https://orcid.org/0000-0001-5445-5869

\section{Research Article}

Keywords: Evapotranspiration, Eco-hydrology, Landscape ecology, Ventilated-chambers, Remote sensing models

Posted Date: September 24th, 2021

DOI: https://doi.org/10.21203/rs.3.rs-928797/v1

License: (c) (i) This work is licensed under a Creative Commons Attribution 4.0 International License.

Read Full License 
1 Selection of remote sensing images and evapotranspiration models on complex land surfaces for a humid karst catchment

3 Rongfei Zhang ${ }^{1,2,3,4 *}$

$4{ }^{1}$ College of Environment and Ecology, Chongqing University, Chongqing, 400045,

5 China;

$6 \quad{ }^{2}$ Key Laboratory of the Three Gorges Reservoir Region's Eco-environment, Ministry of

7 Education, Chongqing University, Chongqing 400045, China

$8 \quad{ }^{3}$ Huanjiang Observation and Research Station for Karst Ecosystem, Key Laboratory of 9 Agro-ecological Processes in Subtropical Region, Institute of Subtropical Agriculture, 10 Chinese Academy of Sciences, Changsha 410125, Hunan, China;

$11{ }^{4}$ Guangdong Key Laboratory of Integrated Agro-environmental Pollution Control and 12 Management, Guangdong Institute of Eco-Environment \&Soil Science, Guangzhou 13510650 , Guangdong, China

14 Email: rongfei330@cqu.edu.cn

15 Key points

16 1. The PML model using Landsat-8 images performed better than other models.

17 2. Surface parameters and $E T$ exhibited clear spatial and temporal distributions.

18 3. Control factors of $E T$ show significantly different effects 

types of ecosystems, and ET processes in these ecosystems have been assessed through in-situ measuring and modelling methods. However, it is challenging to measure actual $E T$ and upscale it to regional level. In addition, the accuracy of retrieved parameters from models is usually low for karst landscapes, where the underlying surface is more complex than non-karst landscapes. Due to various porosities and conduits, aquifers in karst landscapes typically show remarkable and rapid responses to precipitation events, leading to serious water stress. Therefore, there is an urgent need to quantify water fluxes to provide reliable evidence for the protection and sustainable management of karst water resources. In this study, five plots were built to observe actual ET based on Thermal Dissipation Probes (TDP), re-designed Ventilated-chamber and Microlysimeters in a karst catchment in southwest China. Then, three models (PenmanMonteith-Leurning, PML; Remote Sensing-Priestley and Taylor, RS-PT; and Hargreaves) were selected to upscale ET estimation to the regional level based on Landsant- 8 and MODIS data. The results showed that: 1) The PML model performed better than other models $(p<0.01)$ with higher $R^{2}$ values $(0.72$ for MODIS images and 0.87 for Landsat-8 images) and smaller $R M S E$ values $\left(1.4 \mathrm{~mm} \cdot\right.$ day $^{-1}$ and $0.8 \mathrm{~mm} \cdot$ day $^{-1}$ for MODIS and Landsat-8 images, respectively); 2) Daily ET exhibited significant seasonal variability and different spatial distribution; 3) ET had a slightly positive correlation with DEM; however, ground temperature had a negative correlation with ET. By combining remote sensing data and upscaling it to the regional level, this study 1 helps improve the accuracy of measured and estimated ET. It suggests that ET is 
42 strongly regulated by vegetation coverage and available energy in subtropical humid

43 karst catchments.

\section{$44 \quad$ Keywords}

45 Evapotranspiration; Eco-hydrology; Landscape ecology; Ventilated-chambers; Remote 46 sensing models

\section{$47 \quad 1$ Introduction}

48 Evapotranspiration (ET) process bonds water, energy cycle and carbon cycles, and

49 nearly $70 \%$ of the precipitation returns to the atmosphere in the form of ET (Zhang et

50 al., 2016). According to the changing law of the value, ET process for ecosystems can

51 be an important climatic predictor of ecosystem health. Therefore, the mastery of 52 ecosystem ET plays a great role in promoting water resources management (Allen and 53 Breshears, 1998; Anderson et al., 2012; Fisher et al., 2017; Jung et al., 2010; Koster et

54 al., 2004; Seneviratne et al., 2006). Accordingly, ET processes of ecosystems in 55 different climatic zones and geomorphological regions around the world have been 56 estimated through in-situ measuring and modelling methods as shown in Table 1. In 57 detail, in-situ measuring methods conclude Micro-lysimeter, Soil heat pulse, Chamber,

58 Micro Bowen ratio energy balance, Eddy covariance method, Sap flow, Biomass59 transpiration relationship, Isotope's methods, and so on. However, it is difficult to use 60 experimental methods to estimate regional ET. Therefore, various models were 61 combined with remote sensing technique, which has been recognized as one of the 62 feasible ways to estimate ET in regional scale, to extend ET estimation level. The basic 
idea of remote sensing technique is energy balance in the vertical direction. In 1997, Jackson first put forwards a simplified method that combining the observation data with remote sensing data to fit evaporation and remote sensing data (Jackson et al., 1977). In 1983, Sequin perfected Jackson's empirical formula (Seguin and Itier, 1983). Since then, Bella established a relationship between daily ET with NDVI and surface temperature by using AVHRR data(Bella et al., 2000). Some scholars established empirical relationship among net radiation, vegetation index, temperature, soil temperature and ET. Overall, empirical statistical models are simple to use but relying on the surface observation data too much (Wang and Liang, 2008). In 1948, Penman proposed two formulas: one is to calculate potential evaporation underlying moist surface and the other is to calculate transpiration of single leaves hole (Penman, 1948). Based on the two formulas, Monteith introduced the concept of surface impedance and got the Penman-Monteith (P-M) formula, which is the foundation for the further study about ET of unsaturated underlying surface. In 1972, Priestley put forward PriestleyTaylor (P-T) model to calculate ET based on the equilibrium vaporization and under the premise of the hypothesis of no advection (Priestley and Taylor, 1972). By combining with the feature space of temperature-vegetation index and quadratic linear interpolation, Jiang and Islam (2001) calculated actual P-T coefficient of different underlying surface. In 1963, Bouchet first put forward the relationship theory of actual and potential ET (Bouchet, 1960). Based on the theory, scholars established a series of calculation models of actual ET, such as the Advection-Aridity model put forward by Brutsaert, the CRAE (Complementary Relationship Areal Evapotranspiration) model 
proposed by Morton, the Granger model established by Granger through combining heat balance principle and aerodynamics based on Dolton evaporation law. In 1981, Jackson presented CWSI (Crop Water shortage Index) (Jackson et al., 1981). Due to the exponential model error in sparse vegetation area is too big, Moran improved the model by using vegetation index and temperature trapezoidal method. SEBAL (Surface Energy Balance Algorithm for Land) model was put forward based on land surface energy balance equation to estimate regional ET by analyzing the net radiation flux. These kinds of remote sensing ET models can be divided into single-layer model and double-layer model out of different exchange ways of surface and near surface atmosphere turbulence heat flux (Bastiaanssen et al., 1998; Kustas et al., 1989).

\section{Insert Table 1 here}

Though various models have been combined with remote sensing images to estimate regional ET in many landscapes, however, it is challenging to measure actual ET and the accuracy of retrieved parameters of models is usually low for karst landscapes, which cover $10 \%$ of the earth's land surface and supply water resources for approximately $25 \%$ of the world's population (Hartmann et al., 2014a). The underlying surface features of karst landscape are more complicated than plain or plateau landscapes, leading to poorer parameters values estimation. For example, Luo et al. (2019) calculated the spatial distribution of soil moisture for a karst catchment and found that the models did not perform well in highly heterogeneous landscapes $\left(R^{2}=\right.$ 0.36). Therefore, accurate ET estimation based models for karst landscapes is more difficult than in regions with a uniform underlying surface. Aquifers in karst landscapes 
typically exhibit significant and rapid responses to precipitation events (Hartmann et al., 2014a), due to various porosities (such as micropores, small fissures and fractures, large fractures and conduits) (Bakalowicz, 2005) and low water retention in thin soil (Liu et al., 2016). Moreover, severe rocky desertification has occurred in many fragile karst ecosystems, mainly due to deforestation and agricultural intensification in recent years (Yang et al., 2016). When rainfall is low, water stress and water shortages occur frequently and rapidly, and there is an urgent need to quantify water fluxes to provide

114 reliable evidence for the protection and sustainable management of karst water resources.

Therefore, this study aims to: 1) Construct and compare remote sensing models to estimate $E T$ at the regional level for karst landscapes; and 2) Characterize ET processes and impact controls for karst ecosystems.

\section{Materials and methods}

\subsection{Study Area} $\left(103^{\circ} 30^{\prime}-105^{\circ} 54^{\prime} \mathrm{E}, \quad 25^{\circ} 36^{\prime}-27^{\circ} 18^{\prime} \mathrm{N}\right)$ covers approximately $7265 \mathrm{~km}^{2}$. It is located in the Wumeng Mountains, the transition region between Yunnan Plateau and Guizhou

124 Plateau. The average elevation of upstream is greater than $2000 \mathrm{~m}$. Midstream elevations range from $1800 \mathrm{~m}$ to $2400 \mathrm{~m}$ and downstream areas are less than $1200 \mathrm{~m}$. Perennial mean precipitation and annual mean temperature of study area are 1336 $\mathrm{mm} \cdot$ year $^{-1}$ and $13-15^{\circ} \mathrm{C}$, respectively. With obvious humid subtropical monsoon 
climate characteristic, approximately $80 \%$ of precipitation during a year falls between May and October. The vegetation types are diverse in the basin, where is dominated by deciduous broad-leaved forest and evergreen broad-leaved forest. HOUZHAI Basin (Fig.1c) is located in the southeastern corner of SANCHA Basin. It covers approximately $81 \mathrm{~km}^{2}$. The elevation ranges from 1220 to $1531 \mathrm{~m}$. The three major soil types are lime soil, yellow loam and rice soil in the catchment (Zhang et al., 2017).

\section{Insert Figure 1 here}

\subsection{Field measurements}

In-situ monitoring was carried out in HOUZHAI Basin (Fig.2). Five cover types were selected to monitor actual ET as shown in Table 2. TDP (Thermal dissipation probes, FLGS-TDP XM1000, Dynamax, USA), connected to a CR 1000 datalogger, were used for forest, orchard and shrub-grass and burned patch to monitor transpiration of trees and shrub. Micro-lysimeters were used to measure soil evaporation. Ventilatedchambers were used to monitor ET for low vegetation, such as grass, shrub, crop and soil. Two micro-meteorological stations (HOBO U30-NRC made by USA Onset Computer Corporation) were set to monitor meteorological factors, i.e. air temperature (Ta), precipitation $(P R C P)$, relative humidity $(R H)$, photosynthetic active radiation (PAR) and wind speed (WS). One is inside the forest, and the other is outside. Timedomain reflectometry probes (CS625) were used to automatic continuous monitor $\theta$ once every five minutes. LAI (Leaf Area Index) was measured using LAI-2200C (LICOR LTD., U.S.) once every 10-15 days. 


\subsection{Sap flow, ventilated chamber, and micro-lysimeters}

Sap flow for trees and shrubs was monitored using the TDP system to calculate transpiration. Two thermocouple probes of the TDP system were implanted in the sapwood of the tree trunk (Granier, 1985; Granier et al., 2000). Then, the temperature difference $\left(T_{d}\right)$ was recorded by these two thermocouples. When transpiration happens in the stem of trees or shrubs, the sap flow in the conduit will make the heated probe cool and inecrease $T_{d}$ between the reference probe and the heated probe. When the sap flow stops at midnight, the temperature difference reaches its maximum $\left(T_{d m}\right)$ (Bosch et al., 2014). The formula to calculate sap is below (Granier et al., 2000):

$S F=S a \times 0.119\left(T_{d m}-T_{d}\right)^{1.231} \times 3600\left[\mathrm{~cm}^{3} \cdot \mathrm{cm}^{-2} \cdot \mathrm{hr}^{-1}\right]$

where $T_{d m}$ is the mean value of the temperature difference between 23:00 pm and 3:00 am of the next morning (Cramer et al., 1999), and $S a$ is the area of trees'sapwood.

Ventilated chambers are able to measure actual ET for crops, shrub, grass, small trees and plantations (Reicosky and Peters, 1977). Its ability to accurate real-time monitoring actual $E T$ for different ecosystems in-site makes the ventilated chamber well known (Greenwood et al., 1982; Greenwood et al., 1985a; Greenwood et al., 1985b). The ventilated chambers made in previous studies were fixed in soil and they were difficult to move and operate. Therefore, we redesigned the ventilated chambers, which were easily portable (Patent No.: ZL 201410756225.X). The redesigned ventilated 
170 chamber has two pipelines connecting the outside air. One is an outlet near the top

171 connected to an aspirator pump by PVC tubing and the other is inlet hole connected

172 with a PVC tube. There are two sensors were inserted in these two pipelines to log the

173 temperature and humidity of air flux. The chamber frames were made by stainless-steel, 174 and covered by lightfast and transparent doors. Then, the chamber can be lifted and

175 placed on the ground with a pedestal. $E T\left(\mathrm{~mm} \cdot\right.$ day $\left.^{-1}\right)$ was estimated according to the

176 following equations:

$177 \quad A H=\frac{217 \times R H \cdot 6.1078 e^{\frac{17.269 t}{237.3+t}}}{T a}\left(\mathrm{~g} / \mathrm{m}^{3}\right)$

$178 E T=\sum_{i=1}^{n} V \cdot A H_{\text {outlet }} i \cdot t-\sum_{i=1}^{n} V \cdot A H_{\text {intlet }} i \cdot t$

179 where $V$ is the flow rate of the pump $\left(\mathrm{m}^{3} \cdot \mathrm{min}^{-1}\right)$ and $A H$ is absolute humidity $\left(\mathrm{g} \cdot \mathrm{m}^{-3}\right)$.

180 For ecosystems with installed TDP and ventilated chambers, ET can be estimated 181 as follows:

$E T=\frac{T_{s u m}}{A}+E T_{v}$

where $T_{\text {sum }}\left(\mathrm{kg} \cdot\right.$ day $\left.^{-1}\right)$ is tree transpiration, $E T_{\mathrm{v}}$ is the $E T$ measured by the ventilated chamber in the understory and $A\left(\mathrm{~m}^{2}\right)$ is the cover area of the trees.

In this study, Micro-lysimeters were used to measure soil evaporation. The Microlysimeters were made by PVC cylinders, the size is $9.5 \mathrm{~cm}$ inner diameter $\times 20 \mathrm{~cm}$ depth PVC cylinders, and the outer diameter of the PVC cylinders was $10 \mathrm{~cm}$ (Boast and Robertson, 1982). The Micro-lysimeters were encased by outer PVC cylinders of slightly larger diameter but of the same depth as the inner PVC cylinders (Balwinder- 
190 Singh et al., 2014). Each cylinder held a undisturbed soil core, which was performed

191 with minimum soil disturbance so that the obtained soil core remained (Allen, 1990).

192 In every plot, there are three Micro-lysimeters were set under vegetation near the

193 ventilated chamber. The cylinders were weighed every two hours from 06:00 to 20:00

194 to determine water loss.

\section{$195 \quad 2.4$ Remote sensing data and model construction}

Landsat-8 and MODIS images of SANCHA and HOUZHAI Basins were used in

this study. Landsat-8 images were obtained from http://glovis.usgs.gov/, and MODIS

198 products were downloaded from http://ladsweb.nascom.nasa.gov/data/search.html.

199 DEM data were obtained from the geospatial data cloud (http://www.gscloud.cn/), with a spatial resolution is $90 \mathrm{~m}$. Before retrieving relevant surface parameters, radiation calibration and atmospheric correction were performed on the Landsat- 8 data to maintain the same spatial resolution as the visible light and near infrared band. The original MODIS leaf area product data were re-projected using MRT (MODIS Reprojection Tool) software to convert to the krasovsky-albert equivolume projection, then resampled to a spatial resolution of $1 \mathrm{~km}$. After that, remote sensing images were spliced and cut based on the boundary of the study area map. To improve the quality of MODIS-LAI data, the Savitzky-Golay (S-G) filter was used to reduce noise in the MOD152A products. Then, the image time sequence was reconstructed. Using TIMESAT software, the original LAI was smoothed and the key step was setting

210 relevant parameters (including the sliding window size, fitting peak parameters and 211 iteration times), according to the vegetation growth pattern. 
Taylor) and Hargreaves models were selected and compared to simulate ET. The PML

214 model was optimized by the PM model (Penman-Monteith) to describe the biophysics

215 of evaporation $(E)$ from land surfaces. It can be expressed as equation (5). ET is the

$218 \lambda E=\frac{\varepsilon A+\left(\frac{\rho c_{p}}{\gamma}\right) D_{a} G_{a}}{\varepsilon+1+\frac{G_{a}}{G_{s}}}$

$\lambda E T=\frac{\varepsilon A_{c}+\left(\frac{\rho c_{p}}{\gamma}\right) D_{a} G_{a}}{\varepsilon+1+\frac{G_{a}}{G_{S}}}+\frac{f \varepsilon A_{S}}{\varepsilon+1}$

$G_{C}=\frac{g_{s x}}{k_{Q}} \ln \left[\frac{Q_{h}+Q_{50}}{Q_{h} \exp \left(-k_{Q} L\right)+Q_{50}}\right]\left[\frac{1}{1+\frac{D_{a}}{D_{50}}}\right]$

$G_{S}=G_{C}\left[\frac{1+\frac{\tau G_{a}}{(\varepsilon+1) G_{C}}\left[f-\frac{(\varepsilon+1)(1-f) G_{C}}{G_{a}}\right]+\frac{G_{a}}{\varepsilon G_{i}}}{1-\tau\left[f-\frac{(\varepsilon+1)(1-f) G_{C}}{G_{a}}\right]+\frac{G_{a}}{\varepsilon G_{i}}}\right]$

222 where $\lambda\left(\lambda=2.45, \mathrm{MJ} \cdot \mathrm{kg}^{-1}\right)$ is the latent heat of $E, \varepsilon=\frac{s}{\gamma}, \gamma\left(\gamma=0.66 \mathrm{hPa} \cdot{ }^{\circ} \mathrm{C}^{-1}\right)$ is the

223 psychrometric constant and $S\left(\mathrm{kPa} \cdot{ }^{\circ} \mathrm{C}^{-1}\right)$ is the slope of the curve relating saturation

224 water vapor pressure and $\mathrm{Ta} . A\left(\mathrm{~W} \cdot \mathrm{m}^{-2}\right)$ denotes the available energy absorbed by the

225 surface $(R n-G$, net absorbed radiation minus soil heat flux $) . D_{a}(\mathrm{~Pa})$ denotes the water

226 vapor pressure of the air, $G_{a}\left(\mathrm{~m} \cdot \mathrm{s}^{-1}\right), G_{c}\left(\mathrm{~m} \cdot \mathrm{s}^{-1}\right)$ and $G_{s}\left(\mathrm{~m} \cdot \mathrm{s}^{-1}\right)$ denote the aerodynamic

227 conductance, canopy conductance and the surface conductance, respectively. Parameter

$228 f$ denotes the soil moisture index, $g_{s x}$ is stomatal conductance. $A_{c}\left(\mathrm{~W} \cdot \mathrm{m}^{-2}\right)$ and $A_{s}\left(\mathrm{~W} \cdot \mathrm{m}^{-}\right.$

$229 \mathrm{~S}^{2}$ ) are the available energy absorbed by the canopy and soil, respectively. The fraction

230 of the total available energy absorbed by the canopy and by the soil are given 
respectively by $A_{C} / A=1-\tau$ and $A_{S} / A=\tau$, where $\tau=\exp \left(-k_{A} \cdot L A I\right), k_{A}$ is an extinction coefficient for available energy and $L A I\left(\mathrm{~m}^{2} \cdot \mathrm{s}^{-2}\right)$ is leaf area index. $Q_{h}=0.8 A$, and fixed values are $Q_{50}=30 \mathrm{~W} \cdot \mathrm{m}^{-2}, G_{a}=0.033, k_{Q}=0.6, D_{50}=1.0 \mathrm{kPa}$. 2004). Because interception loss can be responsible for approximately $13-22 \%$ of the evaporation component of total ET losses in various ecosystems, therefore, it should be taken into account when estimating ET over large land masses. The modified RS - PT model can be expressed as equation (10) - (13).

239

$\lambda E T=\alpha\left[\frac{\triangle\left(R_{n}-G\right)}{\triangle+\gamma}\right]$

$240 \lambda E T=\lambda T_{c}+\lambda E_{s}+\lambda E_{i c}+\lambda E_{w s}$

241 (10)

$242 \lambda \lambda T_{c}=\left(1-F_{w e t}\right) f_{v} f_{T} \alpha \frac{\Delta}{\Delta+\gamma} R_{n c}$

243

$244 \lambda E_{s}=\left(1-f_{w e t}\right) f_{s m} \alpha \frac{\Delta}{\Delta+\gamma}\left(R_{n s}-G\right)$

$245 \quad(12)$

$246 \lambda E_{i c}=f_{w e t} \alpha \frac{\Delta}{\Delta+\gamma} R_{n c}$

$247 \lambda E_{w s}=f_{w e t} \alpha \frac{\Delta}{\Delta+\gamma}\left(R_{n s}-G\right)$

248

249 where $\alpha$ is a dimensionless coefficient ranging from $1.08 \pm 0.01$ and $1.34 \pm 0.05$, with 250 average of 1.26 according to empirical data from numerous sites around the world 
(Priestley and Taylor, 1972), $T_{\text {opt }}=25^{\circ} \mathrm{C}, a_{g}=0.18 . \lambda$ is the latent heat of vaporization

252 of water $\left(\lambda=2.45, \mathrm{MJ} \cdot \mathrm{kg}^{-1}\right), R_{\mathrm{n}}$ is the net radiation $\left(\mathrm{MJ} \cdot \mathrm{m}^{-2} \cdot \mathrm{d}^{-1}\right), \gamma$ is the psychrometric

253 constant $\left(\gamma=0.66 \mathrm{hPa} \cdot{ }^{\circ} \mathrm{C}^{-1}\right.$;) (Ding et al., 2013; Pereira, 2004; Utset et al., 2004). $T_{c}$,

$254 E_{s}, E_{i c}$ and $E_{w s}$ denote vegetation transpiration, soil evaporation, vegetation interception

255 evaporation and wet soil surface evaporation, respectively. Parameter $f_{v}$ is fraction of

256 green vegetation $\left(f_{v}=\frac{N D V I-N D V I_{\min }}{N D V I_{\max }-N D V I_{\min }}\right), f_{t}$ is the plant temperature constraint $\left(f_{t}\right.$ $\left.257=\exp \left[-\left(\frac{T_{a}-T_{o p t}}{T o p t}\right)^{2}\right]\right), f_{s m}$ is soil moisture constraint $\left(f_{s m}=\left(\frac{1}{D T}\right)^{D T / D T_{\text {max }}}\right), f_{\text {wet }}$ is the 258 relative surface wetness $\left(f_{\text {wet }}=f_{s m}^{4}\right) . G$ is the soil heat flux $\left(G=a_{g} R_{n}\left(1-f_{v}\right), \mathrm{W} \cdot \mathrm{m}^{-2}\right)$, $259 R_{n c}$ and $R_{n s}$ are net radiation to the vegetation $\left(R_{n c}=R_{n} f_{v}\right)$ and net radiation to the soil $260\left(R_{n s}=R_{n}\left(1-f_{v}\right)\right)$, respectively (Fisher et al., 2008; Qiaozhen et al., 2011). model only requires measurements of the maximum and minimum air temperature data, and it can be expressed as (Zanetti et al., 2019):

$E T=0.0023 \frac{R_{a}}{\lambda} \sqrt{\left(T a_{\max }-T a_{\min }\right)}\left(T a_{\text {mean }}+17.8\right)$

$R_{n}=k_{R_{S}} R_{a} \sqrt{\left(T a_{\max }-T a_{\min }\right)}$

where $R_{n}\left(\mathrm{MJ} \cdot \mathrm{m}^{-2} \cdot \mathrm{d}^{-1}\right)$ is the solar radiation, $\lambda$ is the latent heat of vaporization of water $\left(\lambda=2.45, \mathrm{MJ} \cdot \mathrm{kg}^{-1}\right) \cdot R_{a}\left(\mathrm{MJ} \cdot \mathrm{m}^{-2} \cdot \mathrm{d}^{-1}\right)$ is the extraterrestrial radiation with a value of approximately $1367 \mathrm{~W} \cdot \mathrm{m}^{-2}$ (Allen et al., 1998), $k_{R s}\left({ }^{\circ} \mathrm{C}^{-0.5}\right)$ is the adjustment coefficient. The value of $k_{R s}$ falls within the range of $0.16-0.19$. For interior regions more than 20 $\mathrm{km}$ from the ocean, the value is $0.16 . \operatorname{Ta}_{\max }\left({ }^{\circ} \mathrm{C}\right), \operatorname{Ta} a_{\text {min }}\left({ }^{\circ} \mathrm{C}\right)$ and $\operatorname{Ta} a_{\text {mean }}\left({ }^{\circ} \mathrm{C}\right)$ denote the max temperature, the min temperature and the mean temperature, respectively (Zanetti 
et al., 2019).

\section{Evaluation of Model Performance}

Taylor diagrams were used to evaluate model performance, which are polar-style graphs (Yao et al., 2017). Taylor diagrams include the centered root-mean-square error (RMSE), the correlation coefficient $(R)$ and the standard deviation (STD) between observed and modeled ET. In addition, the determination efficiency $\left(R^{2}\right)$ was used in model evaluation (Gupta et al., 2009; Hartmann et al., 2013). These indices were calculated by the following equations:

$$
R^{2}=\left[\frac{\sum_{t=1}^{n}\left(Q_{m}^{t}-\bar{Q}_{m}\right)\left(Q_{O}^{t}-\bar{Q}_{O}\right)}{\sqrt{\sum_{t=1}^{n}\left(Q_{m}^{t}-\bar{Q}_{m}\right)^{2}} \sqrt{\sum_{t=1}^{n}\left(Q_{O}^{t}-\bar{Q}_{O}\right)^{2}}}\right]^{2}
$$

$R M S E=\sqrt{\frac{\sum_{t=1}^{n}\left(Q_{m}^{t}-Q_{O}^{t}\right)^{2}}{n}}$

where $n$ is the number of data sets, $r$ is the linear correlation coefficient between simulations and observations, $Q_{\mathrm{m}}^{\mathrm{t}}$ is the modeled value, $Q_{o}^{t}$ is observed data $\overline{Q_{\mathrm{m}}}$ is average modelled value, and $\overline{Q_{0}}$ is the average observed value.

\section{Results}

\subsection{Performance of different models}

Fig.2a - f show the relationships between observed and simulated daily ET by different models based on MODIS and Landsat-8 images. Fig.3 shows the Taylor diagrams for observed and simulated daily ET from the different models using MODIS and Landsat-8 images. As shown in Fig.2a - f and Fig.3, Landsat-8 images (the average 
$291 R^{2}$ and $R M S E$ are $0.81,0.9 \mathrm{~mm} \cdot \mathrm{day}^{-1}$, respectively) were more suitable for simulating

292 daily ET than MODIS images (the average $R^{2}$ and $R M S E$ are $0.68,1.3 \mathrm{~mm} \cdot \mathrm{day}^{-1}$,

293 respectively) for all three models. The PML model $(p<0.01)$ had a higher $R^{2}(0.72$ for

294 MODIS images and 0.87 for Landsat- 8 images $)$ and lower $R M S E\left(1.4 \mathrm{~mm} \cdot \mathrm{day}^{-1}\right.$ and

$2950.8 \mathrm{~mm} \cdot$ day $^{-1}$ for MODIS and Landsat-8 images, respectively), and therefore performed

296 better than the other models. The Hargreaves model performed ?? $\left(R^{2}=0.65\right.$ for

297 MODIS images and $R^{2}=0.77$ for Landsat- 8 images) than any other model using two

298 kinds of images.

\section{Insert Figure 3 here}

\subsection{Spatial-temporal distribution of $E T$}

Fig.4a - f show the spatial distribution of daily ET in different seasons for

HOUZHAI Basin. As shown in Fig.4, daily ET exhibited marked seasonal variability.

Mean daily ET in HOUZHAI Basin during the growing period (May, June and August:

Mean $\left.=3.77 \mathrm{~mm} \cdot \mathrm{day}^{-1}\right)$ is obvious higher than in the non-growing period (December,

March and April: Mean $\left.=1.6 \mathrm{~mm} \cdot \mathrm{day}^{-1}\right)$. As shown in Fig.5a - f, mean daily ET in

SANCHAHE River Basin also exhibited seasonal variability. The mean daily ET was

$1.7 \mathrm{~mm} \cdot$ day $^{-1}, 3.6 \mathrm{~mm} \cdot$ day $^{-1}, 2.6 \mathrm{~mm} \cdot$ day $^{-1}$ and $0.8 \mathrm{~mm} \cdot$ day $^{-1}$ in spring (February), respectively. 


\section{Insert Figure 5 here}

As shown in Fig.6, the monthly ET of HOUZHAI Basin exhibited noticeable seasonal variability and strongly affected by vegetation cover type. Monthly ET values for cropland, forest and orchards in June and August were all greater than 100 $\mathrm{mm} \cdot \mathrm{month}^{-1}$; however, monthly ET for shrub-grass never reached $85 \mathrm{~mm} \cdot \mathrm{month}^{-1}$. The six-month average $E T$ values were $84.5 \mathrm{~mm} \cdot \mathrm{month}^{-1}, 95.5 \mathrm{~mm} \cdot \mathrm{month}^{-1}, 89.5$ $\mathrm{mm} \cdot \mathrm{month}^{-1}, 69.5 \mathrm{~mm} \cdot \mathrm{month}^{-1}$ and $54.4 \mathrm{~mm} \cdot \mathrm{month}^{-1}$ for cropland, forest, orchard,

319 fired patch and shrub-grass, respectively. As shown in Fig.7a - b, Annual average ET were $634.7 \mathrm{~mm} \cdot$ year $^{-1}$ and $589 \mathrm{~mm} \cdot \mathrm{year}^{-1}$ for HOUZHAI Basin and SANCHA River Basin, respectively. The distribution of annual average ET exhibited marked regional differences. As shown in Fig.6a, annual ET for the eastern HOUZHAI Basin is clearly higher than in the western part. The values in the eastern part mainly ranged from 600 -750 , and values in the west mainly ranged from 500-650. Fig. $7 \mathrm{~b}$ shows the distribution of annual ET for SANCHA Basin. On the whole, values in the south-central region were higher than in the northern region. The distribution of ET was not uniform, which may have been related to the underlying surface cover types.

\section{Insert Figure 7 here}

\subsection{Relationship between $E T$ and retrieved surface parameters}

As shown in Fig.8, the surface parameters values exhibited distinct seasonality. 
in June and August (summer), respectively. However, it was only 0.1 in December (winter). Similar seasonality was observed in the seasonal variability process of Gs, Rn and GTa. The average Gs was $0.025 \mathrm{~m} \cdot \mathrm{s}^{-1}, 0.034 \mathrm{~m} \cdot \mathrm{s}^{-1}, 0.042 \mathrm{~m} \cdot \mathrm{s}^{-1}$ and $0.016 \mathrm{~m} \cdot \mathrm{s}^{-1}$ for April, June, August and December, respectively. The values of Rn mainly ranged from $114-500 \mathrm{~W} \cdot \mathrm{m}^{-2}$ on 14 April and the average April value was $254 \mathrm{~W} \cdot \mathrm{m}^{-2}$. Values ranged from $281-610 \mathrm{~W} \cdot \mathrm{m}^{-2}$ and $207-630 \mathrm{~W} \cdot \mathrm{m}^{-2}$ on $15 \mathrm{June}$ and 11 August, respectively. The average values were $477 \mathrm{~W} \cdot \mathrm{m}^{-2}$ and $485 \mathrm{~W} \cdot \mathrm{m}^{-2}$ for the two months, respectively. GTa values ranged from $289-307 \mathrm{~K}, 300-315 \mathrm{~K}, 303-317 \mathrm{~K}$ and 282-298 K on 14 April, 15 June, 11 August and 17 December, respectively. Average GTa value was 295 K, 308 K, $311 \mathrm{~K}$ and $287 \mathrm{~K}$ for April, June, August and December, respectively.

As shown in Fig. 9, ET had a slight positive correlation with DEM, and $R^{2}$ was 0.18 and 0.11 on 14 April and 18 June, respectively. There was a clear positive correlation between ET and LAI, Gs and Rn. $R^{2}$ for the three controls were greater than 0.60 and 0.54 on 14 April and 18 June, respectively. However, GTa exhibited a negative correlation with ET, and $R^{2}$ was 0.61 and 0.74 on 14 April and 18 June, respectively.

\section{Insert Figure 8 here}

\section{Insert Figure 9 here}

\section{Discussion}

As a key parameter for retrieving ET, GTa is essential in constructing various models. Compared with SPOT, Gaofen and Sentinel remote sensing images and data, only MODIS and Landsat data contain thermal infrared bands, which is the basis for 
retrieving GTa (Bhattacharya et al., 2010; Bourras, 2006; Shen et al., 2016). Therefore, MODIS and Landsat- 8 were selected as remote sensing data in this study. As shown in Fig. 2 and Fig. 3, PML models using Landsat- 8 images performed slightly better than those using MODIS data. This may be because the spatial resolution of Landsat- 8 images $(30 \mathrm{~m})$ is higher than those of MODIS data $(1000 \mathrm{~m})$. More validation data observed in experimental spots can be identified and corresponded with satellite data. Consequently, more samples decreased the systematic error and increased the accuracy of the models based on Landsat-8 images. The RS-PT model didn't perform as well as the PML model in our study, which may have been related to the complex and varied surface. For the five ecosystems, crop rotation and deciduous trees create high variability in stomatal resistance over the course of the year. Consequently, simulated values for canopy resistance $\left(r_{c}\right)$ and canopy surface resistance $\left(r_{s}^{c}\right)$ might be imprecise (Irmak et al., 2013; Whitley et al., 2009). In other words, values of the calibrated ' $\alpha$ ' parameter for ecosystems were difficult to unify and specify. The Hargreaves model also perfommed slightly poorer than the PML model. This may have been because $k_{R s}$ was readjusted in our study and the parameter was influenced by wind speed at $2 \mathrm{~m}$ hight (Martinez-Cob and Tejero-Juste, 2004). However, there were only two meteorological stations in experimental plots and, previous studies have demenstrated that wind speed is usally not reliable at many stations (Shiri et al., 2013). As a result, the parameter of $k_{R s}$ was less precise in this study.

In our study, daily ET for both HOUZHAI (Fig. 4) and SANCHAHE (Fig. 5) Basins both exhibited seasonality. This finding was similar to previous studies in 
various climatic zones, including cold climates, temperate climates, tropical systems and arid/semi-arid regions (Li et al., 2012; Parka et al., 2008; Shao et al., 2012; Tanaka et al., 2008; Yang and Zhou, 2011). During the study period, the annual mean potential ET was approximately $1102 \mathrm{~mm} \cdot \mathrm{year}^{-1}$, which is similar with those results in the same bioclimatic zone (Chen et al., 2015; Tian et al., 2018; Yao et al., 2014). For example, annual potential ET mainly ranged from $950-1350 \mathrm{~mm} \cdot \mathrm{year}^{-1}$ in southwestern China over eight years (2008-2016) (Tian et al., 2018). The annual potential ET calculated by Yao et al. (2014) from 1982-2010 was between 800-1400 mm·year ${ }^{-1}$ in the same zone. Chen et al. (2015) calculated 50-year (1956-2006) actual annual ET for Guangdong Province, which was in a similar latitude as our study area, and results showed that actual annual ET was within 600-1200 $\mathrm{mm} \cdot \mathrm{year}^{-1}$. In our study, actual annual ET was lower than in Sichuan and Guangdong provinces, with annual ET values of 634.7 $\mathrm{mm} \cdot$ year $^{-1}$ and $589 \mathrm{~mm} \cdot \mathrm{year}^{-1}$ for HOUZHAI and SANCHAHE Basins, respectively. Previous studies have demenstrated that ET was mainly related to temperature, precipiation, solar radiation, soil water content $(S W C)$ and leaf area index (LAI) (Parka et al., 2008; Shao et al., 2012; Tanaka et al., 2008; Yang and Zhou, 2011). In our study, the basins were located in the transition region between Yunnan plateau and Guizhou plateau. The average elevation is higher than in Sichuan and Guangdong provinces, and average daily temperatures were much lower than those regions. Consequently, annual ET was also lower. Daily ET was highest during the growing seasons. In our study, annual ET in forest, orchard and cropland was always higher than in fired patch and shrub-grass ecosystems. The vegetation coverage and density of conducting tissue (e.g. 
398 LAI) both contributed to ET seasonality and the differing spatial distributions

399 (Dickinson et al., 1991; Ge et al., 2011; Kite, 2000; Kite and Droogers, 2000; Tanaka

400 et al., 2008). Morever, this region is generally underdeveloped, overpopulated and

401 characterized by severe rocky desertification (Hartmann et al., 2014b; Nie et al., 2012;

402 Yang et al., 2017). The water retention capacity of the thin soil layer is low, and water

403 flows away through surface runoff and crevasses. Therefore, the upper limit of ET was

404 constrained (Liu et al., 2016).

405 The values for soil moisture index $(f)$ and stomatal conductance $\left(g_{s x}\right)$ in the PML

406 model were $0.017 \mathrm{~m} \cdot \mathrm{s}^{-1}$ and 1 , respectively. Previous studies have demonstrated that $g_{s x}$

407 often falls the range of $0-0.020 \mathrm{~m} \cdot \mathrm{s}^{-1}$, and $f$ ranges from $0-1$. When the value of $f$ is

408 closer to 1 , the climate is wetter (Leuning et al., 2008). NDVI reflects vegetation

409 coverage and its values range between -1 and 1 . Where vegetation is denser, the value

410 of NDVI is closer to 1. As shown in Fig. 7, the evolution of retrieved NDVI was

411 consistent with seasonality and vegetation growth in this study. This demonstrated that

412 the retrieved NDVI was trustable (Rocchini, 2009). Previous studies concluded that Gs

413 was related to NDVI and values in the karst areas of southwestern China mainly ranged

414 from $0.020-0.040$ during the growing seasons (Xu et al., 2018). The results were

415 similar to our study. Compared with the North China plain, where vegetation cover is

416 lower, Gs was higher in our study (Hu et al., 2018). GTa and Rn exhibited clear spatial

417 distributions in our study. This may have been because towns, asphalt roads and

418 artificial buildings have a strong capacity to absorb heat during the day, so GTa and Rn

419 were higher in towns than mountain areas and croplands where the canopy density of 
420

421 Rigden and Li, 2017; Wang et al., 2019). In our study, ET had slight positive

422 correlations with DEM, LAI, Gs and Rn. In essence, the DEM effect was influenced by

423 vegetation, because NDVI values at high elevations were higher than that at lower

424 elevation. By the same principle, the distribution of LAI was consistent with NDVI and

425 elevation in the study area. On the contrary, GTa was higher in towns where vegetation

426 is sparse, and it was nagetively correlated with ET. Previous studies showed that the

427 main controlling environmental factors for ET differed with vegetation type (such as

428 crops, grass and trees), climate (such as water and energy availability) and landscapes

429 (such as plains, plateaus and karst depressions) (Beven, 1979; Coleman and Decoursey,

430 1976; Gong et al., 2006; Nouri et al., 2017; Sharifi and Dinpashoh, 2014). Overall, ET

431 is more strongly controlled by energy availability as the climate becomes wetter, and

432 more controlled by water availability as the climate becomes drier.

\section{5. Conclusions}

In this study, five plots were built to observe actual ET using refitted ventilated-

435 chamber, thermal dissipation probes and micro-lysimeters in a subtropical humid karst

436 catchment. Then, three models (Penman-Monteith-Leurning, PML; Remote Sensing-

437 Priestley and Taylor, RS-PT; and Hargreaves) were selected to upscale ET estimation

438 to the regional level using Landsant-8 and MODIS data. The results showed that the

439 PML model performed the best, probably due to the fact that the spatial resolution of

440 Landsat-8 images $(30 \mathrm{~m})$ was higher than the MODIS data $(1000 \mathrm{~m})$. Additional

441 validation data observed in experimental spots were identified and corresponded with 
442 satellite data. Vegetation coverage and the density of conducting tissue (e.g. LAI) both

443 contributed to ET seasonality and the spatial distribution differences.

\section{$444 \quad$ Acknowledgments}

445 This study was supported by the GDAS' Project of Science and Technology

446 Development (2020GDASYL-20200103078) and Natural Science Youth Foundation

447 of Guangdong Province (2020A1515111060). We thank anonymous reviewers and the 448 editorial team.

\section{Data Availability Statement}

450 All data and models are available from the authors upon request.

\section{Ethical Approval}

452 The authors declare no conflict of interest.

453 Consent to Participate

454 The authors consent to participate.

\section{Consent to Publish}

456 The authors consent to publish.

\section{Authors Contributions}

458 Rongei Zhang: Conceptualization, Methodology, Software, Validation, Writing-

459 Original Draft, Review \& Editing, Resources, Project administration, funding 460 acquisition.

$461 \quad$ Funding 
462 This study is supported by GDAS' Project of Science and Technology Development

463 (2020GDASYL-20200103078), Natural Science Youth Foundation of Guangdong

464 Province (2020A1515111060) and National Natural Science Foundation of China

465 (42101036).

466 Additional information

467 Publisher's Note

468 Springer Nature remains neutral with regard to jurisdictional claims in published maps 469 and institutional affiliations.

\section{Reference}

471 Allen, C.D. and Breshears, D.D., 199 8. Drought-induced shift of a forest-woodland ecotone: 472 Rapid landscape response to climate variation. Proceedings of the National Academy of Sciences of the U nited States of America, 9 5(25): 14839 -14 842.

Allen, R.G., Pereira, L.S. and Raes, D., 199 8. Crop evapotranspiration- Guidelines for computing crop water requirements. FAO I rrig and Drain Paper No. 56, Rome. .

476 Allen, S.J., 199 0. Measurement and Estimation of Evaporation from Soil under Sparse Barley Crops in Northern Syria. Agr Forest Meteorol, 49 (4 ): 29 1-309.

Anderson, R.G., Jin, Y.F. and Goulden, M.L., 2012. Assessing regional evapotranspiration and water balance across a Mediterranean montane climate gradient. Agr Forest Meteorol, 166: 10 22.

481 Bakalowicz, M., 2005. Karst groundwater: a challenge for new resources. Hydrogeol J, 13(1): 14 8160.

Balwinder-Singh, Eberbach, P.L. and Humphreys, E., 2014 . Simulation of the evaporation of soil water beneath a wheat crop canopy. Agr Water Manage, 135: 19 -26.

Bastiaanssen, W.G.M. et al., 199 8. A remote sensing surface energy balance algorithm for land (SEBAL) - 2. Validation. J Hydrol, 212(1-4 ): 213-229 .

487 Bella, D.L., Kwon, Y.H., Hirschberger, L.L. and Stipanuk, M.H., 2000. Post-transcriptional regulation of cysteine dioxygenase in rat liver. Adv Exp Med Biol, 4 83: 71-85.

489 Beven, K., 1979 . Sensitivity Analysis of the Penman-Monteith Actual Evapotranspiration 
Estimates. J Hydrol, 44 (3-4 ): 169 -19 0.

491

492

493

494

495

496

497

498

499

500

501

502

503

504

505

506

507

508 509

510

511

512

513

514

515

516

517

518

519

520

521

522

523

524

Bhattacharya, B.K., Mallick, K., Patel, N.K. and Parihar, J.S., 2010. Regional clear sky evapotranspiration over agricultural land using remote sensing data from I ndian geostationary meteorological satellite. Journal of Hydrology, 387(1-2): 65-80.

Boast, C.W. and Robertson, T.M., 19 82. A Micro-Lysimeter Method for Determining Evaporation from Bare Soil - Description and Laboratory Evaluation. Soil Sci Soc Am J, 4 6(4 ): 689 696.

Bosch, D.D., Marshall, L.K. and Teskey, R., 2014 . Forest transpiration from sap flux density measurements in a Southeastern Coastal Plain riparian buffer system. Agricultural and Forest Meteorology, 187: 72-82.

Bouchet, R.J., 19 60. Evapotranspiration Potentielle Dun Couvert Vegetal - Sa Signification Et Sa Mesure a Partir De Levaporation Sous Abri. Cr Hebd Acad Sci, 251(12): 1231-1233.

Bourras, D., 2006. Comparison of five satellite-derived latent heat flux products to moored buoy data. Journal of Climate, 19 (24 ): 629 1-6313.

Chen, X .Z. et al., 2015. 50-year evapotranspiration declining and potential causations in subtropical Guangdong province, southern China. Catena, 128: 185-19 4 .

Coleman, G. and Decoursey, D.G., 19 76. Sensitivity and Model Variance Analysis Applied to Some Evaporation and Evapotranspiration Models. Water Resour Res, 12(5): 873-879 .

Cramer, V.A., Thorburn, P.J. and Fraser, G.W., 1999 . Transpiration and groundwater uptake from farm forest plots of Casuarina glauca and Eucalyptus camaldulensis in saline areas of southeast Queensland, Australia. Agricultural Water Management, 39 (2-3): 187-204 .

Dickinson, R.E., Henderson-Sellers, A., Rosenzweig, C. and Sellers, P.J., 199 1. Evapotranspiration Models with Canopy Resistance for U se in Climate Models - a Review. Agricultural and Forest Meteorology, 54 (2-4 ): 373-388.

Ding, R.S., Kang, S.Z., Li, F.S., Zhang, Y.Q. and Tong, L., 2013. Evapotranspiration measurement and estimation using modified Priestley-Taylor model in an irrigated maize field with mulching. Agr Forest Meteorol, 168: 14 0-14 8.

Fisher, J.B. et al., 2017. The future of evapotranspiration: Global requirements for ecosystem functioning, carbon and climate feedbacks, agricultural management, and water resources. Water Resour Res, 53(4 ): 2618-2626.

Fisher, J.B., Tu, K.P. and Baldocchi, D.D., 2008. Global estimates of the land- atmosphere water flux based on monthly AVHRR and I SLSCP-I I data, validated at 16 FLU X NET sites. Remote Sensing of Environment, 112(3): 9 01-9 19 .

Fu, P. and Weng, Q.H., 2016. A time series analysis of urbanization induced land. use and land cover change and its impact on land surface temperature with Landsat imagery. Remote 
Ge, Z.M. et al., 2011. I mpacts of changing climate on the productivity of Norway spruce dominant stands with a mixture of Scots pine and birch in relation to water availability in southern and northern Finland. Tree Physiol, 31(3): 323-338.

Gong, L.B., X u, C.Y., Chen, D.L., Halldin, S. and Chen, Y.Q.D., 2006. Sensitivity of the PenmanMonteith reference evapotranspiration to key climatic variables in the Changjiang (Yangtze River) basin. Journal of Hydrology, 329 (3-4 ): 620-629 .

Granier, A., 19 85. A New Method of Sap Flow Measurement in Tree Stems. Annales Des Sciences Forestieres, 4 2(2): 19 3-200.

Granier, A., Biron, P. and Lemoine, D., 2000. Water balance, transpiration and canopy conductance in two beech stands. Agr Forest Meteorol, 100(4 ): 29 1-308.

Greenwood, E.A.N., Beresford, J.D., Bartle, J.R. and Barron, R.J.W., 19 82. Evaporation from Vegetation in Landscapes Developing Secondary Salinity U sing the Ventilated-Chamber Technique .4 . Evaporation from a Regenerating Forest of Eucalyptus Wandoo on Land Formerly Cleared for Agriculture. J Hydrol, 58(3-4 ): 357-366.

Greenwood, E.A.N., Klein, L., Beresford, J.D. and Watson, G.D., 19 85a. Differences in Annual Evaporation between Grazed Pasture and Eucalyptus Species in Plantations on a Saline Farm Catchment. Journal of Hydrology, 78(3-4 ): 261-278.

Greenwood, E.A.N., Klein, L., Beresford, J.D., Watson, G.D. and Wright, K.D., 19 85b. Evaporation from the U nderstorey in the Jarrah (Eucalyptus-Marginata Don Ex Sm) Forest, Southwestern Australia. J Hydrol, 80(3-4 ): 337-34 9.

Gupta, H.V., Kling, H., Yilmaz, K.K. and Martinez, G.F., 2009 . Decomposition of the mean squared error and NSE performance criteria: I mplications for improving hydrological modelling. J Hydrol, 377(1-2): 80-9 1.

Hartmann, A., Barbera, J.A., Lange, J., Andreo, B. and Weiler, M., 2013. Progress in the hydrologic simulation of time variant recharge areas of karst systems - Exemplified at a karst spring in Southern Spain. Adv Water Resour, $54: 149$-160.

Hartmann, A., Goldscheider, N., Wagener, T., Lange, J. and Weiler, M., 2014 a. Karst water resources in a changing world: Review of hydrological modeling approaches. Rev Geophys, 52(3): 218-24 2.

Hartmann, A. et al., 2014 b. Modeling spatiotemporal impacts of hydroclimatic extremes on groundwater recharge at a Mediterranean karst aquifer. Water Resour Res, 50(8): 6507 6521.

He, F. et al., 2014. Simulating global and local surface temperature changes due to Holocene anthropogenic land cover change. Geophysical Research Letters, 4 1(2): 623-631. 
Hu, X .L., Shi, L.S., Lin, L., Zhang, B.Z. and Zha, Y.Y., 2018. Optical-based and thermal-based surface conductance and actual evapotranspiration estimation, an evaluation study in the North China Plain. Agr Forest Meteorol, 263: $4 \quad 4 \quad 9$-4 64 .

I rmak, S., Mutiibwa, D., Payero, J., Marek, T. and Porter, D., 2013. Modeling soybean canopy resistance from micrometeorological and plant variables for estimating evapotranspiration using one-step Penman-Monteith approach. Journal of Hydrology, 507: 1-18.

Jackson, R.D., I dso, S.B., Reginato, R.J. and Pinter, P.J., 19 81. Canopy Temperature as a Crop Water-Stress I ndicator. Water Resour Res, 17(4 ): 1133-1138.

Jackson, R.D., Reginato, R.J. and I dso, S.B., 19 77. Wheat Canopy Temperature - Practical Tool for Evaluating Water Requirements. Water Resour Res, 13(3): 651-656.

Jiang, L. and I slam, S., 2001. Estimation of surface evaporation map over southern Great Plains using remote sensing data. Water Resour Res, 37(2): 329 -34 0.

Jung, M. et al., 2010. Recent decline in the global land evapotranspiration trend due to limited moisture supply. Nature, 4 67(7318): 9 51-9 54 .

Kite, G., 2000. U sing a basin-scale hydrological model to estimate crop transpiration and soil evaporation. Journal of Hydrology, 229 (1-2): 59 -69.

Kite, G. and Droogers, P., 2000. Comparing evapotranspiration estimates from satellites, hydrological models and field data - Preface. Journal of Hydrology, 229 (1-2): 1-2.

Koster, R.D. et al., 2004 . Regions of strong coupling between soil moisture and precipitation. Science, 305(5687): 1138-1140.

Kustas, W.P. et al., 1989 . Determination of Sensible Heat-Flux over Sparse Canopy U sing Thermal I nfrared Data. Agr Forest Meteorol, 44 (3-4 ): 19 7-216.

Leuning, R., Zhang, Y.Q., Rajaud, A., Cleugh, H. and Tu, K., 2008. A simple surface conductance model to estimate regional evaporation using MODI S leaf area index and the PenmanMonteith equation. Water Resources Research, 44 (10): 652-655.

Li, D. and Wang, L., 2019 . Sensitivity of Surface Temperature to Land U se and Land Cover Change-I nduced Biophysical Changes: The Scale I ssue. Geophysical Research Letters, 4 6(16): 9 678-9 689 .

Li, Z., Zheng, F.L. and Liu, W.Z., 2012. Spatiotemporal characteristics of reference evapotranspiration during 19 61-2009 and its projected changes during 2011-209 9 on the Loess Plateau of China. Agr Forest Meteorol, 154 : 14 7-155.

Liu, M.X ., X u, X .L., Wang, D.B., Sun, A.Y. and Wang, K.L., 2016. Karst catchments exhibited higher degradation stress from climate change than the non-karst catchments in southwest China: An ecohydrological perspective. J Hydrol, 535: 173-180. 
595

596

597

598

599

600

601

602

603

604

605

606

607

608

609

610

611

612

613

614

615

616

617

618

619

620

621

622

623

624

625

626

627

628

Luo, W. et al., 2019 . U AV based soil moisture remote sensing in a karst mountainous catchment. Catena, $174: 4$ 78-4 89 .

Martinez-Cob, A. and Tejero-Juste, M., 2004 . A wind-based qualitative calibration of the Hargreaves ETO estimation equation in semiarid regions. Agricultural Water Management, 64 (3): 251-264 .

Nie, Y.P., Chen, H.S., Wang, K.L. and Yang, J., 2012. Water source utilization by woody plants growing on dolomite outcrops and nearby soils during dry seasons in karst region of Southwest China. J Hydrol, 4 20: 264 -274.

Nouri, M., Homaee, M. and Bannayan, M., 2017. Quantitative Trend, Sensitivity and Contribution Analyses of Reference Evapotranspiration in some Arid Environments under Climate Change. Water Resour Manag, 31(7): 2207-2224.

Parka, H., Yamazaki, T., Yamamoto, K. and Ohta, T., 2008. Tempo-spatial characteristics of energy budget and evapotranspiration in the eastern Siberia. Agr Forest Meteorol, 14 8(12): $1990-2005$.

Penman, H.L., 194 8. Natural Evaporation from Open Water, Bare Soil and Grass. Proc R Soc Lon Ser-A, 19 3(1032): 120-\&.

Pereira, A.R., 2004 . The Priestley-Taylor parameter and the decoupling factor for estimating reference evapotranspiration. Agr Forest Meteorol, 125(3-4 ): 305-313.

Priestley, C.H.B. and Taylor, R.J., 19 72. Assessment of Surface Heat-Flux and Evaporation U sing Large-Scale Parameters. Mon Weather Rev, 100(2): 81-+ .

Qiaozhen, M.U ., Zhao, M. and Steven, W., 2011. I mprovements to a MODI S global terrestrial evapotranspiration algorithm. Remote Sensing of Environment, 115(8): 1781-1800.

Reicosky, D.C. and Peters, D.B., 19 77. Portable Chamber for Rapid Evapotranspiration Measurements on Field Plots. Agronomy Journal, 69 (4 ): 729 -732.

Rigden, A.J. and Li, D., 2017. Attribution of surface temperature anomalies induced by land use and land cover changes. Geophysical Research Letters, 44 (13): 6814 -6822.

Rocchini, D., 2009 . Commentary on Krishnaswamy et al. - Quantifying and mapping biodiversity and ecosystem services: $U$ tility of a multi-season NDVI based Mahalanobis distance surrogate. Remote Sensing of Environment, 113(5): 904 -9 06.

Seguin, B. and I tier, B., 19 83. U sing Midday Surface-Temperature to Estimate Daily Evaporation from Satellite Thermal I r Data. I nt J Remote Sens, 4 (2): 371-383.

Seneviratne, S.I ., Luthi, D., Litschi, M. and Schar, C., 2006. Land-atmosphere coupling and climate change in Europe. Nature, 44 3(7108): 205-209 .

Shao, Q.X ., Traylen, A. and Zhang, L., 2012. Nonparametric method for estimating the effects of 
629

climatic and catchment characteristics on mean annual evapotranspiration. Water Resour Res, 48.

Sharifi, A. and Dinpashoh, Y., 2014 . Sensitivity Analysis of the Penman-Monteith reference Crop Evapotranspiration to Climatic Variables in I ran. Water Resources Management, 28(15): $5465-5476$.

Shen, H.F., Huang, L.W., Zhang, L.P., Wu, P.H. and Zeng, C., 2016. Long-term and fine-scale satellite monitoring of the urban heat island effect by the fusion of multi-temporal and multi-sensor remote sensed data: A 26 -year case study of the city of Wuhan in China. Remote Sensing of Environment, 172: 109 -125.

Shiri, J., Nazemi, A.H., Sadraddini, A.A., Landeras, G. and Marti, P., 2013. Global cross-station assessment of neuro-fuzzy models for estimating daily reference evapotranspiration. Journal of Hydrology, 4 80(4 ): 4 6- 57.

Tanaka, N. et al., 2008. A review of evapotranspiration estimates from tropical forests in Thailand and adjacent regions. Agricultural and Forest Meteorology, 14 8(5): 807-819 .

Tian, Y., Zhang, K.J., X u, Y.P., Gao, X .C. and Wang, J., 2018. Evaluation of Potential Evapotranspiration Based on CMADS Reanalysis Dataset over China. Water, 10(9).

U tset, A., Farre, I ., Martinez-Cob, A. and Cavero, J., 2004 . Comparing Penman-Monteith and Priestley-Taylor approaches as reference-evapotranspiration inputs for modeling maize water-use under Mediterranean conditions. Agr Water Manage, 66(3): 205-219 .

Wang, C.Y., Li, Y.B., Myint, S.W., Zhao, Q.S. and Wentz, E.A., 2019 . I mpacts of spatial clustering of urban land cover on land surface temperature across Koppen climate zones in the contiguous U nited States. Landscape and U rban Planning, 192.

Wang, K.C. and Liang, S.L., 2008. An improved method for estimating global evapotranspiration based on satellite determination of surface net radiation, vegetation index, temperature, and soil moisture. J Hydrometeorol, 9 (4 ): 712-727.

Whitley, R., Medlyn, B., Zeppel, M., Macinnis-Ng, C. and Eamus, D., 2009 . Comparing the Penman-Monteith equation and a modified Jarvis-Stewart model with an artificial neural network to estimate stand-scale transpiration and canopy conductance. J Hydrol, 373(12): $256-266$.

X u, J.M., Wu, B.F., Yan, N.N. and Tan, S., 2018. Regional Daily ET Estimates Based on the GapFilling Method of Surface Conductance. Remote Sensing, 10(4).

Yang, F.L. and Zhou, G.S., 2011. Characteristics and modeling of evapotranspiration over a temperate desert steppe in I nner Mongolia, China. J Hydrol, 39 6(1-2): 139 -14 7.

Yang, J. et al., 2016. Effects of Napier grass management on soil hydrologic functions in a karst landscape, southwestern China. Soil \& Tillage Research, 157: 83- 92. 
664
Yang, J. et al., 2017. Effects of "Grain for Green" program on soil hydrologic functions in karst landscapes, southwestern China. Agr Ecosyst Environ, 24 7: 120-129 .

Yao, Y.J., Zhao, S.H., Zhang, Y.H., Jia, K. and Liu, M., 2014. Spatial and Decadal Variations in Potential Evapotranspiration of China Based on Reanalysis Datasets during 19 82-2010. Atmosphere, 5(4 ): 737-754.

Yao, Y.Y. et al., 2017. I mproving global terrestrial evapotranspiration estimation using support vector machine by integrating three process-based algorithms. Agr Forest Meteorol, 242 : $55-74$.

Zanetti, S.S., Dohler, R.E., Cecilio, R.A., Pezzopane, J.E.M. and X avier, A.C., 2019 .Proposal for the use of daily thermal amplitude for the calibration of the Hargreaves-Samani equation. Journal of Hydrology, 571: 19 3-201.

Zhang, M., Zhou, Y., Tian, X . and Huang, X ., 2017. Study on spatial heterogeneity and reserve estimation of soil organic carbon in a small karst catchment. Acta Ecologica Sinica, 37(22): $7647-7659$.

Zhang, Y.Q. et al., 2016. Multi-decadal trends in global terrestrial evapotranspiration and its components. Sci Rep-U k, 6 . 


\section{TABLES}

696 Table 1. Comparison of relevant studies for ET observation methods and models for

697 different various ecosystems in various landscapes.

698 Table 2. Baseline information for the five land cover types

\section{FIGURES}

Fig.1 Study area. Photo (d) shows the ventilated chamber; (e) and (h) show Thermal Dissipation Probes (TDPs); (f) shows a micro-lysimeter; (g) shows a meteorological station.

Fig.2 Relationships (linear regression) between observed and simulated ET using

704 different models based on MODIS and Landsat-8 images. Fig.2a-c are based on

705 MODIS images and Fig.2d-f are based on Landsat- 8 images. Note that $R^{2}$ and $R M S E$ denote the coefficient of determination and root-mean-square error, respectively.

Fig.3 Taylor diagrams of observed and simulated daily ET using different models based on MODIS and Landsat- 8 images. Dotted circular lines connecting the $x$ and $y$ axes 

coefficient values $(R)$, and the green curves denote $R M S E$ values.

Fig.4 Spatial-temporal distribution of daily ET for HOUZHAI Basin.

Fig.5 Spatial-temporal distribution of daily ET for HOUZHAI Basin.

Fig.6 Monthly ET for different vegetation cover types

Fig.7 Spatial distribution of annual ET for HOUZHAI and SANCHAHERiver Basins

Fig.8 Spatial distribution of surface parameters in different seasons. Fig.7a-d, Fig.7e-h,

Fig.7i-1 and Fig. $7 \mathrm{~m}-\mathrm{p}$ represent NDVI, ground surface conductance, net radiation and ground temperature, respectively. NDVI, Gs, Rn and GTa are normalized vegetation index, ground surface conductance, net radiation and ground temperature, respectively.

Fig.9 Correlation analysis between control factors and ET in different seasons. $R^{2}$ and $P$ are the coefficient of determination and p-value, respectively. 
733 Table 1. Comparison of relevant studies for ET observation methods and models for

734 different various ecosystems in various landscapes.

Methods

Methods

Micro-lysimeter

Soil of cropland

Yu et al.

(2016)

Heitman et al.

Soil heat pulse

Previous

Observation

studies
Bare soil

(2008)
Central US/Plain/Temperate

Northwest China/Loess

$$
\text { plateau/Semi-arid }
$$

Stannard and Shrubs

Weltz (2006)

Holland et al. Vines
Micro Bowen ratio energy balance
(2013)
Southwest US/Piedmont

$$
\text { plain/Arid desert }
$$

Southeast US/Coastal

plain/Subtropical climate 
Southeast

Eddy covariance

method

Sap flow

Biomass-transpiration

relationship

One-source model

Two-source model

Cherry orchard

Cotton, grapes and

olive trees

Ts-VI model

Empirical model

Savanna

Whole-ecosystems
Denmead et al.

Australian/Temperate humid (1996)

climate/Coastal lowland

\section{Zeppel et al. Australia/Liverpool}

(2008)

plains/Temperate

Ben-Gal et al. Israel/Valley/Mediterranean

climate

Central

Wang et al.

Kenya/Plateau/Tropical

(2012)

savanna climate

Turkey/Irrigated

Bastiaanssen

(2000) basin/Mediterranean climate

Juhasz and Hungary/Plain/Continental

Hrotko (2014) temperate climate

Murray and

Verhoef

$N A$

(2007)

Yan and

American/Various

Shugart (2010) landscapes and climate 
Pemnan-Montheith

equation

Assimilation method

agricultural

and temporal upscaling

ecosystem (Corn)

Forest, Orchard,

Micro-lysimeter, Sap

Cropland, shrub-

Observition flow, Ventilated

grass and Fired

This study
(2008)

Cai et al.

(2007)

East of

\section{Crow et al.}

American/Plain/Temperate

continental climate

\section{Southwest China/karst}

landscape/humid subtropical

monsoon and climate

PML, RS-PT,

Model

patch

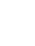


744

745

746

747

748

749

750

751 Table 2. Baseline information for the five land cover types

\section{Data}

Types

Vegetation species

ET measurement

Experimental

Growth

spacing

spacing (day) stage

(min)

Quercus fabri HancelAlbizia

julibrissin Durazz./Toona

sinensis/Platycarya strobilacea

Forest

TDP

5

Continuous Mar-Nov

Sieb.et Zucc./Kalopanax

septemlobus (Thunb.)

Koidz./Populus adenopodaMaxim. 
Grass and soil

Toona sinensis/Pyrus, i, f./Catalpa

TDP

bungei C. A. Mey.

\section{Orchard}

Bare soil

Maize

Cropland

Oilseed rape

Coriaria nepalensis

Wall./Pyracantha fortuneana

(Maxim.) Li

Shrub-grass

Burned

Grass

TDP

Ventilated-

chamber

TDP

5

Continuous

Ventilated-

Grass and soil

patch

10-15
5

Continuous

5

10-15

Continuous

Mar-Nov

10-15

Mar-Jun

Dec-Mar

Mar-Nov

5

10-15

Mar-Nov

chamber 

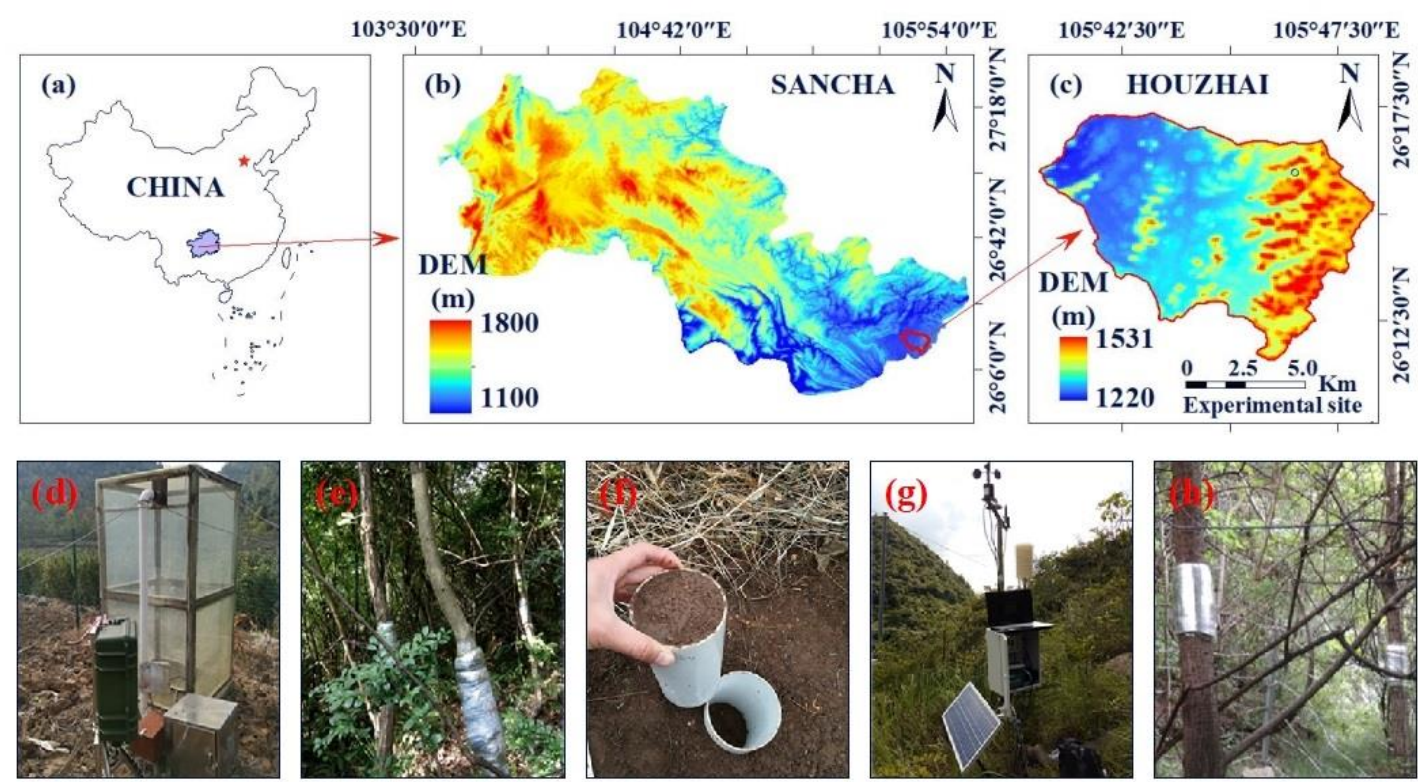

Fig.1 Study area. Photo (d) shows the ventilated chamber; (e) and (h) show Thermal

764 Dissipation Probes (TDPs); (f) shows a micro-lysimeter; (g) shows a meteorological station. 

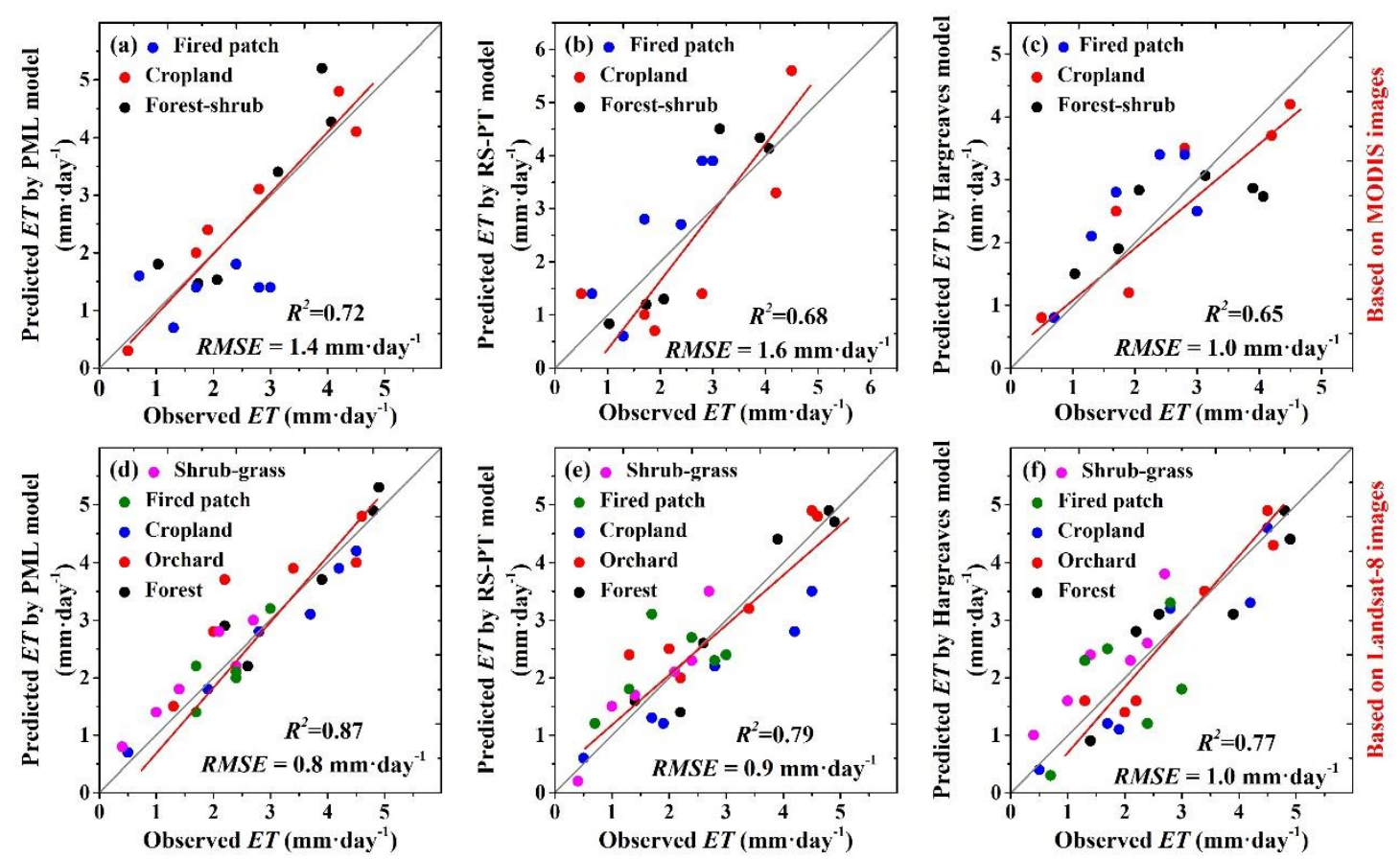

Fig.2 Relationships (linear regression) between observed and simulated ET using

773 different models based on MODIS and Landsat-8 images. Fig.2a-c are based on

775 denote the coefficient of determination and root-mean-square error, respectively. 


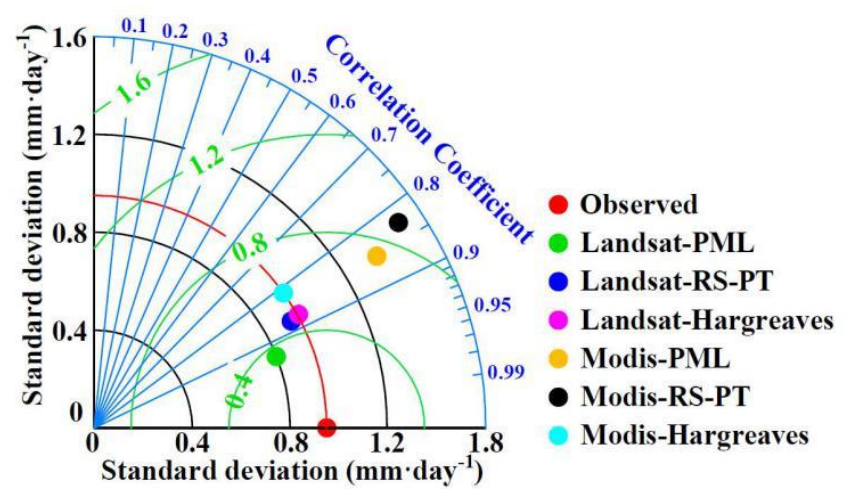

785 Fig.3 Taylor diagrams of observed and simulated daily ET using different models based

786 on MODIS and Landsat-8 images. Dotted circular lines connecting the $x$ and $y$ axes represent the standard deviations (STD), dotted radial lines are the correlation coefficient values $(R)$, and the green curves denote $R M S E$ values. 

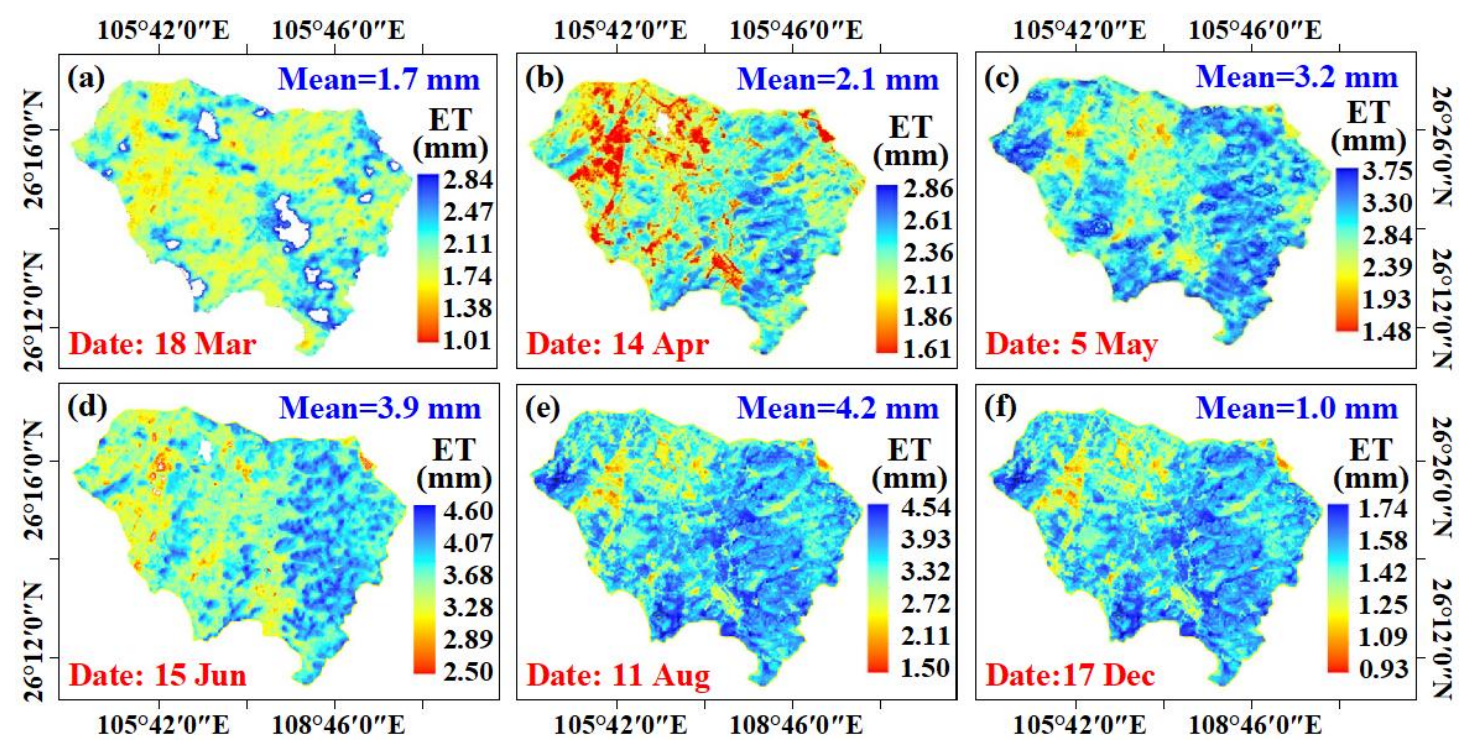

$799 \quad$ Fig.4 Spatial-temporal distribution of daily ET for HOUZHAI Basin.

800

801

802

803

804

805

806

807 

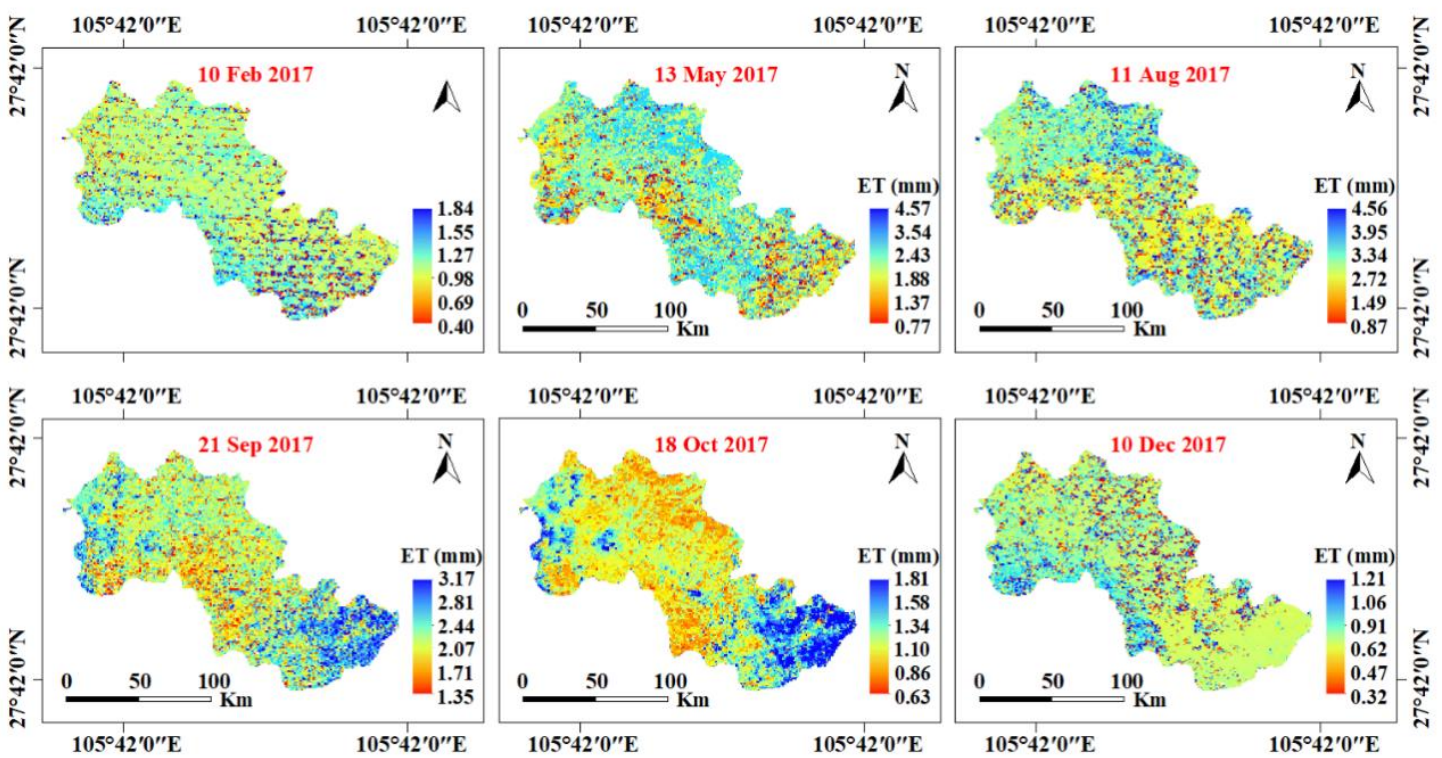

810 Fig.5 Spatial-temporal distribution of daily ET for HOUZHAI Basin.

813

814

815

816

817

818 


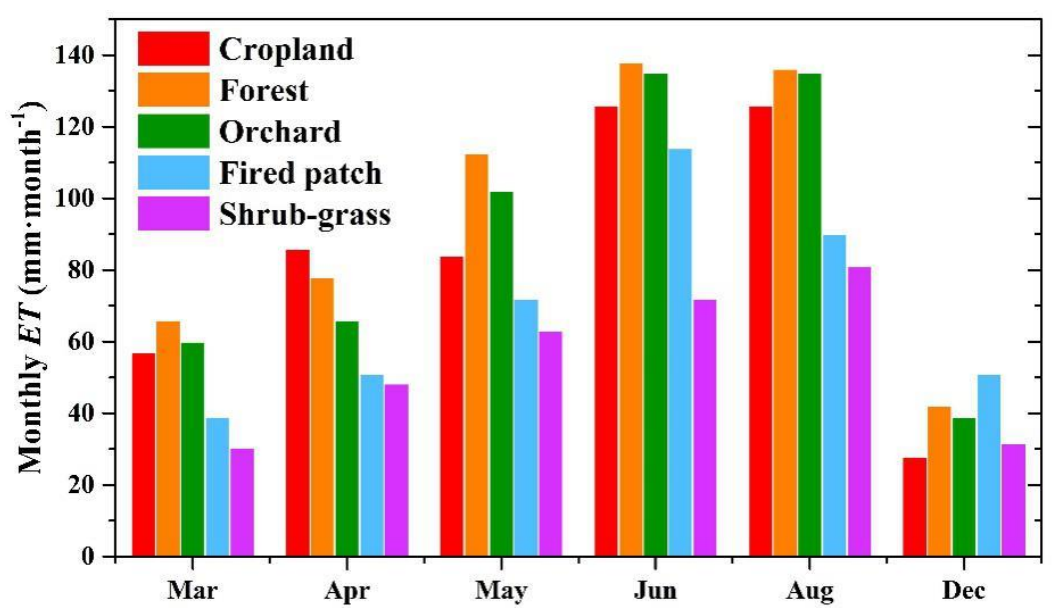

820 Fig.6 Monthly ET for different vegetation cover types

821

822

823

824

825

826

827

828

829

830 


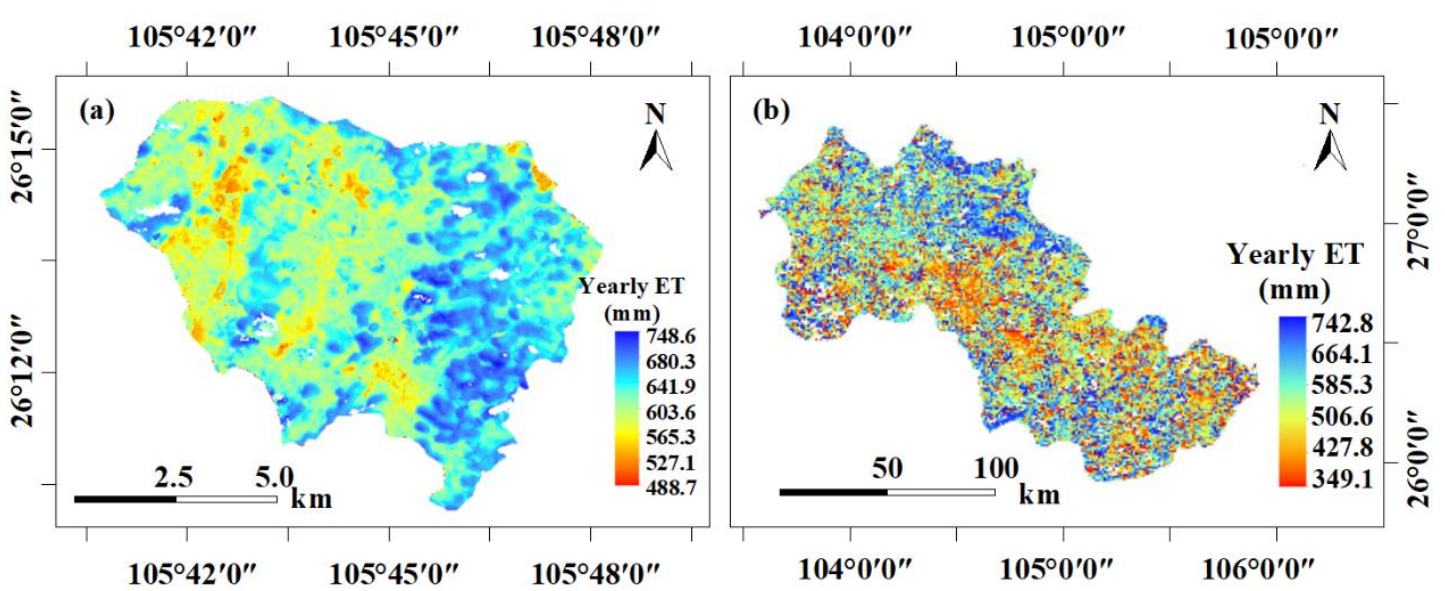

833 Fig.7 Spatial distribution of annual ET for HOUZHAI and SANCHAHERiver Basins

836

837

838

839

840

841

842

843 

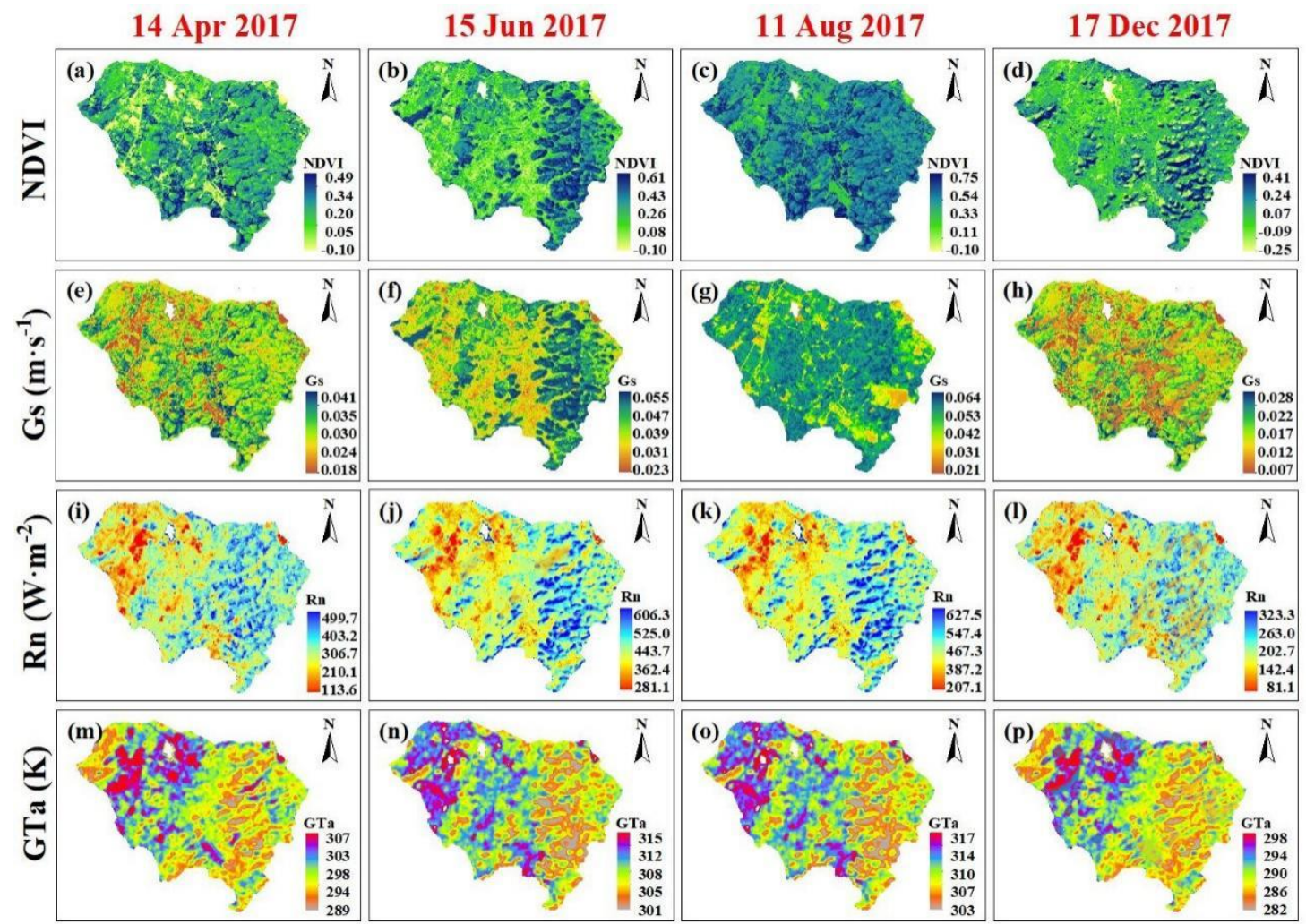

845 Fig.8 Spatial distribution of surface parameters in different seasons. Fig.7a-d, Fig.7e-h,

846 Fig.7i-1 and Fig.7m-p represent NDVI, ground surface conductance, net radiation and

847 ground temperature, respectively. NDVI, Gs, Rn and GTa are normalized vegetation

848 index, ground surface conductance, net radiation and ground temperature, respectively.

849

850

851

852

853 


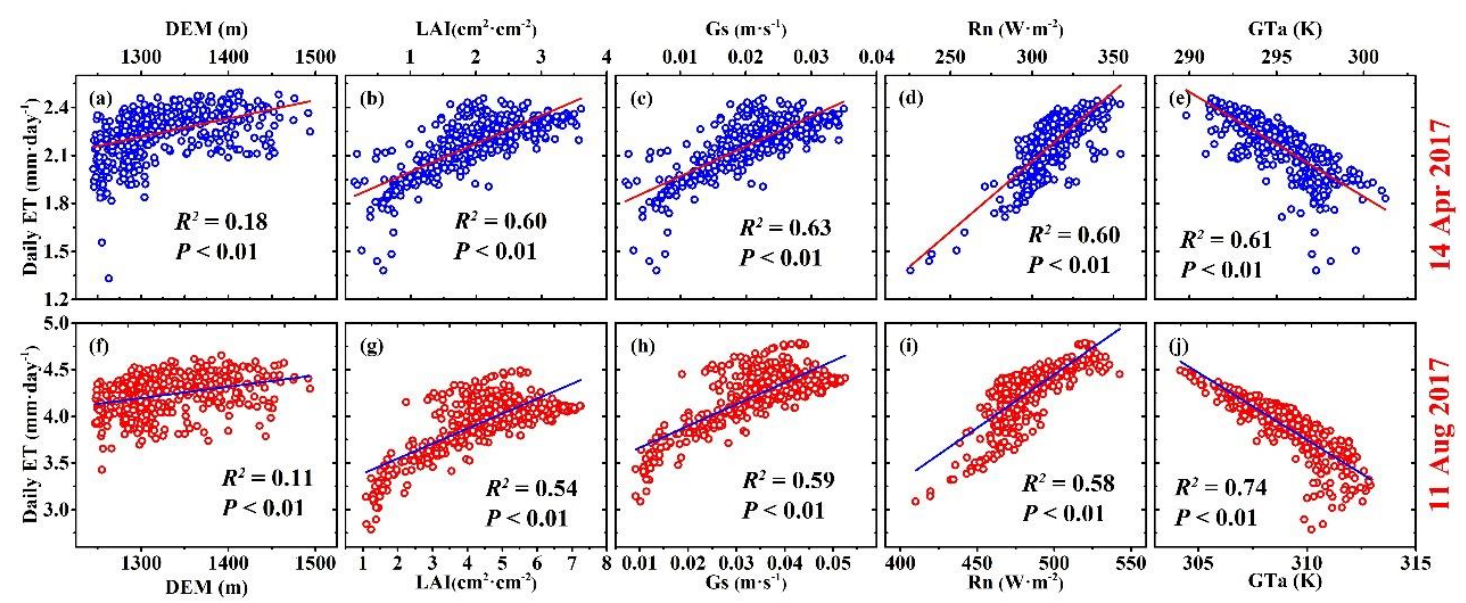

858 Fig.9 Correlation analysis between control factors and ET in different seasons. $R^{2}$ and

$859 P$ are the coefficient of determination and p-value, respectively. 